Available online:

http://journal.imla.or.id/index.php/arabi

IMLA

Arabi : Journal of Arabic Studies, 5 (1), 2020, 25-32

DOI: http://dx.doi.org/10.24865/ajas.v5i1.195

\title{
HIGH VARIETY VS LOW VARIETY CULTURE IN THE ARABIC LANGUAGE : THE TENSIONS BETWEEN FUSHÂA AND 'ÂMIYYA IN THE CONTEMPORARY ARAB WORLD
}

\author{
Yoyo, Abdul Mukhlis, Thonthowi, Ferawati \\ Universitas Ahmad Dahlan, Yogyakarta, Indonesia \\ E-mail : yoyo@bsa.uad.ac.id
}

\begin{abstract}
Arabic language, in its sociological context is divided into two varieties: fushā and 'amiyya. Arabic fushà is the official language and perceived as the language of Islam. In contrast to the fushā, 'amiyya is the language used by the Arab people in their daily conversations. However, this 'amiyya is considered as inferior. The method used in this study was qualitative that stressed the interaction between language and its sociological context. The method assumed that social and political events affected language use in a particular society. The paper tries to re-popularize the two terms used by Ferguson that are "high variety" $(H)$ and "low variety" $(L)$ culture in analyzing the two languages varieties. Besides, the paper explores the tension of the two languages through contemporary social and political events taking place in the Arab World. The Arabic fusha is perceived as a representation of " $H$ " culture because it is a language used in religious literature and official writings, while the 'amiyya referred to as a representation of " $L$ " variety culture because it is used only as a medium of regular communication.
\end{abstract}

Keywords: high variety culture, low variety culture, fushā, 'āmiyya, contemporary Arab

\begin{abstract}
Abstrak
Bahasa Arab dalam konteks sosiologisnya terbagi menjadi dua: fushā dan 'ämiyya. Bahasa Arab fushā merupakan bahasa resmi dan dipersepsikan sebagai bahasa Islam. Berbeda dengan fushā, 'ämiyya merupakan bahasa yang digunakan sehara-hari oleh masyarakat Arab pada umumnya. Meskipun demikian, bahasa 'āmiyya dipandang sebagai bahasa inferior. Penelitian ini menggunakan metode kualitatif yang menekankan pada interaksi bahasa dan kontek sosiologis. Paper ini mencoba mempopularkan kembali dua istilah yang digunakan oleh Ferguson, yaitu istilah "varietas budaya luhur" (L) dan "varietas budaya rendah" (R). Selain itu, paper ini lebih lanjut berupaya untuk mengeksplorasi tensi di antara dua varietas bahasa tersebut melalui konteks sosial politik kontemporer yang terjadi di Dunia Arab. Bahasa Arab fushā dipandang sebagai representasi dari budaya "L" karena ia merupakan bahasa yang digunakan dalam literature Agama dan juga tulisan-tulisan resmi lainnya, sementara bahasa 'āmiyya dipandang sebagai "R" karena ia hanya digunakan sebagai medium komunikasi biasa.
\end{abstract}

Kata Kunci: budaya luhur, budaya rendah, fushā, ‘āmiyya, Arab kontemporer 


\section{Arabi : Journal of Arabic Studies}

\section{Introduction}

In general, Muslim countries are divided into two classifications based on the language used in daily communications. First, those who use the official language of the country that is genealogically has nothing to do with the Arabic language such as Iran, Turkey, Pakistan, Indonesia, Malaysia, Senegal, and Nigeria. Second, the Arab countries that speak Arabic dialects that differ from the Arabic fushä. However, these two types of Muslim countries are aware that they should master formal Arabic to be able to understand the Qur'an and to carry out daily worships. Therefore, Islam without classical Arabic or fushā will never exist (Haeri, 2003).

The significant role of Arabic as the central language for Muslims has attracted the interest of Western scholars. T. Arnold (1864-1930 AD), the author of the Preaching of Islam for example, emphatically stated in his lecture in front of hundreds of Western scholars that the study of the Islamic World or Islamic studies would not be perfect without a good mastery of the Arabic language (Arnold, 1917). Charles Ferguson, another prominent Western scholar, and an American linguist, asserted that the study of the Arabs and the Middle East should be equipped with the necessary competence of the languages used in the Middle East, such as Turkish, Persian, and Arabic (Ferguson, 1964).

However, although Arabic got close attention from Western scholars, the previous studies tended to focus more on cultural issues as well as on Islamic politics such as nationalism and modernism. For example, Clifford Geertz and Ernest Gellner (Haeri, 2000). The previous reviews were lack of any attempts to connect between language and power relations both in the text and in real communication. The study of Arabic came later, mainly during the Renaissance era and afterward. The study of Arabic, with its sociological approaches, only emerged in the $17^{\text {th }}$ century. The first work was conducted by Charles Ferguson, who published his article on Diglossia in 1959 (Ferguson, 1959). It is the first and the most influential work on Arabic sociolinguistic that classified Arabic language into Arabic formal (fushā) and colloquial Arabic ('amiyya) (James Mabry, 2007). In the Diglossia, Ferguson promoted the terms of "high variety" (H) and "low variety" (L) cultures on classifying the use of Arabic language in its formal and informal use (Raddaoui, 2015). In addition, the work of Ferguson, as stated by Owens, marked a shift away from the philological Arabicist tradition-oriented text into the spoken language (Owens, 2001).

Meanwhile, the first Arab author who wrote the study of Arabic in its sociolinguistic perspective was Al-Sa'id Badawi. He was the first Arab writer who classified the modern Arabic language in the Egyptian context (Daher \& Daher, 1987). In his study, Badawi, as explained by Kosoff, classified Arabic in the Egyptian context into five linguistic levels: fushā, contemporary Arabic fushā or Modern Standard Arabic, cultured 'amiyya, literate 'ämiyya, and illiterate 'ämiyya. These five levels share common linguistic roots and penetrate multiple speech communities (Kosoff, 2014). The same study was conducted by Carl Brockelmann in "History of the Arabic Written Tradition." He analyzed the use of non-formal Arabic based on geographical maps with its particular attention to the Arabic phonology and syntax (Rosenhouse, 2011).

Different from previous studies, the paper pays more attention to the tensions between fushā and 'amiyya in the contemporary Arab context with special events refers to the Arab spring as a starting point. In particular, its special emphasis lies in the use of Arabic in real communication, both it is in social media or daily conversation. The first discussion will elaborate on the " $\mathrm{H}$ " status of the fusha in the Arab world, including its linguistic features. The next debate will explore the "L" status of the 'ämiyya and its real use in the Arab world, and it also includes the elaboration on its linguistic features. The last discussion mainly focuses on the tension between fushā and 'ämiyya after the Arab spring by marking some linguistic features that appeared during the revolution. 


\section{Method}

The method used in this study was qualitative that stressed the interaction between language and its sociological context, or which is called 'interactional sociolinguistics' (Gumperz, 1999). The method assumed that social and political events affected language use in a particular society (Young, 1999). The primary data of this research are books and journals on the relation between language and society in the Arab context. Meanwhile, current data on linguistic features during the Arab spring collected from any online resources.

\section{Result and Discussion \\ Fushāas High Variety Culture}

As mentioned early, Arabic fushā has a unique place in Islamic studies. Besides, Arabic also occupies its essential place in the Western scholarly tradition. European scholars began to learn Arabic and start to write some books of Arabic grammar based on their grammatical tradition. Besides, Arabic also started to gain in prestigious universities such as at Leiden University in Holland (Yoyo \& Mukhlis, 2019). These serious attempts began during the $16^{\text {th }}$ century, indicated by the emergence of Arabic grammar in Latin, Germany, and French (Yoyo \& Mukhlis, 2019).

On the other hand, the process of modernization of the Arabic language occurred in the $19^{\text {th }}$ century. This process is triggered by the Arabs' internal consciousness to modernize not only the areas of religious, social, and political thought but Arabic also received its serious attention. They saw that classical Arabic less scientific which enable it compete in the modern world. Therefore, the solutions regarding the process of modernization of Arabic are as follows: (a) the replacement of classical Arabic with a regional Arabic colloquial, (b) the replacement of traditional Arabic writing with a Latin type, and (c) the opening of the door for free and extensive borrowing from western languages (Abu-Absi, 1986).

The first Arab intellectual that attempted to modernize the Arabic language was Rifa'ah Badawi al-Tahtawi (1801-1873 AD), an excellent translator, editor, educator, and reformer of the early modern Arab era. The modernization of the Arabic that at-Tahtawi did when he was in France was to translate European scientific terms into Arabic. It was the first attempt of an Arab scholar on the translation works (Yoyo, 2017a). The concrete attempt on translating scientific terms by al-Tahtawi, for example, is the term "opera," which he turned into ubira (Sawaie, 2000). According to at-Tahtawi, translating scientific words from European into Arabic is a challenging job and requires a high art and skill of translation. Therefore, the translation process done by alTahtawi was a direct translation in which the translated words do not lose their original meaning (Sawaie, 2000).

Arabic openness to different terms that come from European tradition is inevitable. In the political sphere, for example, almost of the political terms adopted from the growing political conditions of the West. Therefore, Bernard Lewis firmly states that at the level of political practices, Islam and Arabic, in particular, do not have a semantically equivalent and fitting term in the Western sense (Lewis, 1991). It means that the Arabic language should adapt Western terms on the political issues in its both original word and meaning.

Furthermore, concrete efforts to standardize Arabic translation of foreign terms continued until the birth of language centers in various Arab countries such as Arab Academy in Beirut in 1919, and Royal of Academy of Cairo in 1932. The purpose of the language centers intended as an effort to unify and standardize terminologies on Western sciences (Elshakry, 2008).

On the one hand, the contiguity of the Arab World with Europe occurred at Napoleon's arrival in Egypt in 1798 (Yoyo, 2017a). The European presence in the Arab world has awakened the political elite on the vital role of Arabic as part of nation-building. In some cases, European invaders in Algeria, for example, tried to replace Arabic with the French language (Benrabah, 2013). Therefore, at the sociolinguistic level, Arabic fushā is seen by the Arab nationalist leaders such as Jurji Zaidan and Ibrahim al-Yajizi as part of the national identity-forming element. 


\section{Arabi : Journal of Arabic Studies}

Besides, other Arab thinkers, al-Afghani, and 'Abduh in particular, made Arabic as part of an essential component of Islamic identity (Daher \& Daher, 1987).

The spread and the use of Arabic fushā in the Arab World, such as Egypt has a long history. Before Islam entered Egypt, the spoken language among the people was Coptic and Greek. However, along with the process of Islamization and Arabization, the use of formal Arabic could not be avoided (Yoyo, 2017b). Since the era of Nahdah and the subsequent of the pan-Arabian period under Nasser's leadership, classical Arabic became the official language as well as a symbol of Arabian identity for both Muslim and non-Muslim. Any attempts to replace the classical Arabic with 'amiyya language has never worked because 'amiyya considered as a weak language. In addition, during the British colonization in Egypt, they did not remove Arabic fushā learning in schools. This language policy was not applied in Morocco. The French invaders withdrew the education of fushā in various schools and substituted it with French knowledge (Haeri, 2003).

In particular, fushā has essential features as follows: 1) it has a complicated grammatical system written by traditional Arab grammarians in the eleven century, 2) it is a highly inflected variety in which the mood, case, number, gender, and all other grammatical function marked by a system which is called as i'rāb, 3) morphologically, fushä distinguishes between single, dual, and plural in number, 4) the lexicon of fushā is very rich, and 5) the fushā is claimed in the literature not to be "natural" as it is not learned natively, rather it is learned formally in school (Rabie, 1992).

The strength of Arab identity awareness also triggered by the Turkish policy that prefers to develop Turkism and replace the Caliphate into a nation-state. The response to what happened in Turkey, the elite of the Arab nationalist leaders, established the Arabic language as the identity of the Arab nation. Not only that, but they also make pan-Arabism as a force to build a new world based on a common language and culture. Besides, Europe also played a significant role in spreading the idea of nationalism through three main channels. First, Arab students studying in Europe then returning to the Arab world with the concept of nationalism. Second, through colonialism, that was the post-French occupation of Egypt era between 1798 and $1801 \mathrm{CE}$. The last, European missionary schools established in the Middle East and Lebanon in particular (Albirini, 2015). These three channels had stimulated the rise of Arab self-awareness and identity and transformed it into nationalism and pan-Arabism.

The power of the Arabic fusha beside its status as the language of religion lies in its importance in political field. Every Arab rulers will always emphasize the importance of fusha because of such an attitude seen as proof that he preserves the Arab heritage and traditions. PanArabism, as previously described, is a concrete form of language politics in the Middle East. Therefore, when it is compared to other countries, there will be no Pan-English or Pan-German terms. It is because these languages are not considered as an element of the foundation of religious identity. Therefore, the maintenance of Arabic fushā as Arab national identity and religion is supported by the central role of the government. When the symptoms of the decreasing ability of the younger generation in the language acquisition of Arabic fusha start to look, then the provisioning effort toward language acquisition is not only merely through educational institutions. They are also mobilizing various trainings and conferences related to the theme (Bassiouney, 2009).

An international organization such as ISESCO (Islamic Educational, Scientific, and Cultural Organization) is one of the institutions that pay full attention to the preservation of the Arabic fushā. They organize various training for Arabic teachers as well as general participants in Arabic teaching and learning. In conclusion, the " $\mathrm{H}$ " status of Arabic fusha because it is used in formal situations such as political speeches, religious activities, academic lectures, and other activities of high cultural domains (Rabie, 1992). 


\section{'Ámiyya as Low Variety Culture}

Arabic, as the official language spoken by almost 22 Arab countries, has a distinct variety between Arabic fushā and 'amiyya. Arab grammarians have described this linguistic situation as "linguistic duality" (Rabie, 1992). This difference mainly lies in the syntactic and morphological levels. Arabic fushā has nominative, genetic, and accusative cases. Meanwhile, 'ämiyya, in particular, is a symbol or national-local identity (self-real) because it attaches to a specific Arab nation. It is an expression of self as well as national pride. Therefore, at the socio-linguistic level, the 'ämiyya language occupies a more significant role than the fusha itself. However, Arabic fushā has a considerable role in printed media both in the form of fiction and non-fiction and also the mass media (Rosenhouse, 2011). In a different perspective, Kaye argued that 'amiyya is the original language because it is well defined in the real spoken by Arab societies (Kaye, 1970).

The debate about the role of Arabic 'ämiyya and fusha arose in the $19^{\text {th }}$ century AD. The question at that time was why 'amiyya cannot be a literal language such as the development of the German and Romanian language in Europe, or Turkish language in Anatolia and surrounding areas. The answer to that question is that the language of fusha is sacred. Therefore, its modern form in the form of Modern Standard Arabic is supremacy (James Mabry, 2007). The fact that 'amiyya is a marginal language and as a representation of low culture, it is proved by the fact that the language is not taught at the academic level. It is not only in the Arab countries but also in foreign universities that only teach standard Arabic (Yoyo \& Mukhlis, 2019).

Nevertheless, 'ámiyya or vernacular language is part of socio-linguistic studies and has produced prominent figures in its field, such as Clive Holes, an expert on the Arab dialect of the Gulf regions (James Mabry, 2007). However, as mentioned earlier, 'ámiyya is a real spoken language; its significance lies in its sociological context. It is used not only in daily speaking but also in the local media such as radio, TV, and even social media.

'Amiyya, in particular, has some linguistic features as follows. First, the term 'amiyya means that it is the language of the masses as a language of communication in the market, home, daily life, and in informal situations. Second, 'ämiyya is different from fushà in syntax and lexicon. The $i$ 'ra $\bar{b}$ or inflections are deleted, the dual is rarely used, and the plural form is simple. Third, phonologically, colloquial Arabic, or 'ämiyya has almost all the sounds of Arabic fushā. Fourth, because it has not been written, 'amiyya reminds limited in its communicative value, and it has been described in the literature as being associated with ignorance and vulgarity (Rabie, 1992). In the negation, for example, colloquial Arabic is different from the negative form in fushā. Negation form in 'amiyya uses $m \bar{a}-s y$ and misy. Má-sy is the so-called discontinuous particle because its two parts are realized as a proclitic and enclitic on the opposite edge of the verb, such as in at-thullāb mā-sâfr-uu-sy (the students did not travel). Meanwhile, misy is the nondiscontinuous particle because it realizes negation as a morphologically independent marker, such as in at-thulläb misy fi al-fashl(the students are not in the class) (Albirini, 2014).

From the external factor, colloquial Arabic or 'amiyya had been used by the British colonial in Egypt on promoting the use of a-miyya not merely as a daily language but also for formal purposes (Stadlbauer, 2010). As a result of this, Arab thinkers and nationalists joined together to counter this challenge by insisting that the fushā is much more superior to the 'amiyya and fusha was the backbone of national identity (Rabie, 1992).

\section{Fushā Versus 'Ámiyya during the Arab Spring}

According to Raddaoui, the Arabic language ranging from 1959 until 2011, has undergone a very significant transformation period. First, the increase in literacy rates among Arab societies between the 1950s and 1960s. Second, the era of the 1980s as the era of 'technologizing of the word.' It is the process of digitalization and computerization of Arabic writings that appeared in the Arabic Website in the 1990s. Third, the transformation of the Arabic language during the Arab Spring period (Raddaoui, 2015). The third period described by Raddaoui may comprehensively 


\section{Arabi : Journal of Arabic Studies}

explain the urgency of the 'amiyya language that gained its momentum in the Arab Spring era. The slogans of the revolution generally expressed in 'amiyya. It is because the majority of the Arabs people use non-formal Arabic more frequently rather than formal Arabic. Thus, although the "amiyya language considered as the " $\mathrm{L}$ " variety culture, it still has the tremendous power shown during the Arab Spring (Raddaoui, 2015).

In the Syrian context, for example, there are new words that appear during the Arab spring and showed that the words initially created by the people to protest the government. For example, the term as-Shuhyu Assadi and Basharun are the nicknames given to the regime and Bashar. The first nickname, al-Shuhyu Assadi, is a word created by the people or the protesters coming from two terms: the adjective of shuhyu means Zionist and the name of Assad. It means that the people believe that Bashar al-Assad is a Zionist who is serving the interest of Israel rather than his own people (Neggaz, 2013). Another word is irhal which means, "go out," which is formal Arabic. However, in its sociolinguistic context, the term has a new meaning that is to throw away the despotic ruling regime. This new meaning will only relevant when it is explained in its sociopolitical context (Garduno, 2012; Michel, 2013). Other Arabic expressions during the Arab Spring events mostly articulated in Arabic 'ämiyya rather than in fushāare musy ahzāb wa lā ikhwān (not a party or ikhwan). It means that revolution took place in Egypt was not in the struggle for any party or for the Islamic Brotherhood; instead, it was intended for democracy and freedom. Therefore, the power of 'amiyya language again lies in its socio-political context.

Arabic fushā, in particular, has its place during the Arab Spring era in the formal media news only. Local Arab News such as al-Masry al-Youm, al-Jazeera, etc., frequently publishes any news on the Arab Spring with its language and opinion (Yoyo, Mukhlis, \& Thonthowi, 2018). However, this formal media is only accessed by literate group of people. Besides, Arabic fusha only covers news on the political events in its official language. In contrast to this, Arabic 'amiyya because it is rooted in the people, the expressions are more creative and expressive (Bruns, Highfield, \& Burgess, 2013). Yemen, on the other side, also experienced linguistic features during the Arab spring. One of them is Yemen revolutionary song which is expressed in the local dialect or 'ämiyya (Raddaoui, 2015).

\section{Conclusion}

From the above discussion, it can be mentioned some of the following findings. First, the Arabic fusha as the " $\mathrm{H}$ " variety culture can still survive because it is the language of the Holy Qur'an. Besides, Arabic modernization continues with the emergence of various modern Arabic institutions. Second, Arabic "amiyya as the "L" variety culture has succeeded in showing its power as a standard folk language. 'Amiyya in the Arab political and social contestation has contributed to play its significant role in overthrowing some of the despotic rulers. The demonstrators used Arabic slogans in 'amiyya during the revolution.

Consequently, the study of the Arabic 'amiyya should have more close attention because this language, in its sociological context, is a central part of the cultural elements of Arab societies. However, the study on the relation between language and culture, which is so-called as sociolinguistic, needs an in-depth analysis not only through literature review but also through field study. In the Indonesian context, it will require many efforts due to far distance between Indonesia and the Arab world.[]

\section{References}

Abu-Absi, S. 1986. "The Modernization of Arabic: Problems and Prospects", Anthropological Linguistics, Vol. 28, No. 3.

Albirini, A. 2014. "The Role of the Colloquial Varieties in the Acquisition of the Standard Variety: The Case of Arabic Heritage Speakers”, Foreign Language Annals, Vol. 47, No. 3. 
Albirini, A. 2015. Modern Arabic Sociolinguistics: Diglossia, Variation, Codeswitching, Attitudes and Identity. London \& NewYork: Routledge.

Arnold, T. W. 1917. "The Study of Arabic", Bulletin of the School of Oriental Studies, University of London, Vol. 1, No. 1.

Bassiouney, R. 2009. Arabic sociolinguistics. Edinburgh: Edinburgh University Press.

Benrabah, M. 2013. Language conflict in Algeria: From colonialism to post-independence, Vol. 154. n.p.: Multilingual matters.

Bruns, A., T. Highfield, \& J. Burgess. 2013. "The Arab Spring and Social Media Audiences: English and Arabic Twitter Users and Their Networks", American Behavioral Scientist, Vol. 57, No. 7.

Daher, N., \& N.Y. Daher. 1987. “Arabic Sociolinguistics: State of the Art”, Al-'Arabiyya, Vol. 20, No. $1 / 2$.

Elshakry, M.S. 2008. "Knowledge in Motion: The Cultural Politics of Modern Science Translations in Arabic", Isis, Vol. 99, No. 4.

Ferguson, C.A. 1959. "Diglossia", Word, Vol. 15, No. 2.

Garduno, M. 2012. "Interpreting Revolutionary Arabic: Terms and Vocabulary in the Language(s) of the Arab Spring", The Arab world: the role of media in the arab world's; symposioum proceedings ; Deutsche Welle Media Dialogue May 2012, Berlin: Vistas Verl.

Gumperz, J. 1999. “On Interactional Sociolinguistic Method”, Talk, Work and Institutional Order: Discourse in Medical, Mediation and Management Settings, Vol. 453.

Haeri, N. 2000. "Form and Ideology: Arabic Sociolinguistics and Beyond", Annual Review of Anthropology, Vol. 29, No. 1.

Haeri, N. 2003. Sacred Language, Ordinary People: Dilemmas of Culture and Politics in Egypt. https://www.springer.com.

Kaye, A.S. 1970. "Modern Standard Arabic and the colloquials", Lingua, Vol. 24.

Kosoff, Z. 2014. "Code-Switching in Egyptian Arabic: A Sociolinguistic Analysis of Twitter", Al'Arabiyya: Journal of the American Association of Teachers of Arabic, Vol. 47, No. 1.

Lewis, B. 1991. The Political Language of Islam. Chicago: University of Chicago Press.

Mabry, T James. 2007. Nationalism, Language and Islam: A Cross-Regional Comparative Study of Muslim Minority Conflict. Pennsylvania: University o f Pennsylvania.

Michel, N.N.H. 2013. “IrHal!”: The Role of Language in the Arab Spring. Georgetown University.

Neggaz, N. 2013. "Syria's Arab Spring: Language, Enrichment in the Midst of Revolution”, Language Discourse \& Society, Vol. 2, No. 2.

Owens, J. 2001. “Arabic sociolinguistics”, Arabica, Vol. 48, No. 4.

Rabie, M.S. 1992. “A Sociolinguistic Study of Diglossia of Egyptian Radio Arabic: An Ethnographic Approach", Unpublished Thesis, The University of Texas at Austin). Retrieved from https://elibrary.ru/item.asp?id=5862069

Raddaoui, A.H. 2015. “Arabic in the Lead-Up to the Arab Spring: Fusion or Diffusion”, Research Result, Vol. 4, No. 6. 
Arabi : Journal of Arabic Studies

Rosenhouse, J. 2011. "Trends of Development in Arabic Dialectology in the 20th Century: A Survey", Zeitschrift Für Arabische Linguistik, Vol. 54.

Sawaie, M. 2000. "Rifa'a Rafi At-Tahtawi and His Contribution to the Lexical Development of Modern Literary Arabic”, International Journal of Middle East Studies, Vol. 32, No. 3.

Stadlbauer, S. 2010. "Language ideologies in the Arabic diglossia of Egypt", Colorado Research in Linguistics, Vol. 22, No. 1.

Young, R. 1999. "Sociolinguistic Approaches to SLA", Annual Review of Applied Linguistics, Vol. 19.

Yoyo. 2017. Pemikiran Arab: Dinamika Intelektual, Ideologi, dan Gerakan. Yogyakarta: Sociality.

Yoyo. 2017. "Pengaruh Bahasa Arab terhadap Identitas Sosio-kultural dan Keagamaan Masyarakat Koptik di Mesir”, CMES Jurnal Studi Timur Tengah, Vol. 10, No. 1.

Yoyo., \& A. Mukhlis. 2019. "Historiography of the Arabic Grammar in Europe: The Legacy of Wright's Arabic Grammar", First International Conference on Progressive Civil Society (ICONPROCS 2019).

Yoyo., A. Mukhlis, \& Thonthowi. 2018. "Investigating the Use of Arabic Terms on Sociopolitical Context during the Arab Spring", Prosiding Pertemuan Ilmiah Internasional Bahasa Arab. 